\title{
Remobilization of HFSE and formation of rhabdophane and corkite-hinsdalite under supergene, highly acidic conditions, Velence Hills, Hungary
}

M. ONDREJKA ${ }^{1 *}$, P. BAČÍK ${ }^{1}$, T. SOBOCKÝ ${ }^{1}$, T. MIKUŠ ${ }^{2}$ R. ŠKODA ${ }^{3}$, J. LUPTÁKOVÁ ${ }^{2}$, P. UHER ${ }^{1}$

${ }^{1}$ Faculty of Natural Sciences, Comenius Univ., Mlynská dolina, Ilkovičova 6, 842 15, Bratislava, Slovakia (correspondence: martin.ondrejka@uniba.sk)

${ }^{2}$ Earth Science Institute, Slovak Academy of Sciences, Ďumbierska 1, 97401, Banská Bystrica, Slovakia

${ }^{3}$ Faculty of Science, Masaryk Univ. Kotlářská 2, 61137 , Brno, Czech Republic

An assemblage of alunite-supergroup minerals (ASM), rhabdophane-group minerals (RGM), goethite and associated clay minerals occurs in Permian A-type microgranite in the eastern part of the Velence Hills, Hungary. The secondary sulfates/phosphates include jarosite, $\mathrm{Pb}$-rich jarosite and alunite, corkite, hinsdalite and rhabdophane-(Ce), -(La) and (Nd). Detailed EPMA and Raman spectroscopy reveal a wide miscibility among RGM end-members and show a rhabdophane-tristramite-brockite solid solution with extensive compositional variation. Moreover, ASM show heterogeneous composition and complex substitution mechanisms within the alunite, beudantite and plumbogummite groups. The formation of this rare mineral assemblage reveals extensive remobilization of REE, Th, U, $\mathrm{P}, \mathrm{S}, \mathrm{Fe}$ and $\mathrm{Pb}$ under supergene conditions. Compositional variations and substitution trends of the RGM indicate that $\mathrm{Th}, \mathrm{U}, \mathrm{Ca}$ and $\mathrm{Pb}$ are incorporated into the rhabdophane structure by a $(\mathrm{Ca}, \mathrm{Pb})^{2+}+(\mathrm{Th}, \mathrm{U})^{4+} \leftrightarrow 2 \mathrm{REE}^{3+}$ substitution mechanism. Consequently, we suggest the following endmember formulae for RGM containing divalent and tetravalent cations: $\left(\mathrm{Ca}_{0.5} \mathrm{Th}_{0.5}\right) \mathrm{PO}_{4} \cdot \mathrm{H}_{2} \mathrm{O}$ for brockite, $\left(\mathrm{Pb}_{0.5} \mathrm{Th}_{0.5}\right) \mathrm{PO}_{4} \cdot \mathrm{H}_{2} \mathrm{O}$ for grayite and $\left(\mathrm{Ca} 0.5 \mathrm{U}_{0.5}\right) \mathrm{PO}_{4} \cdot 2 \mathrm{H}_{2} \mathrm{O}$ for tristramite. The formation of this assemblage is associated with low- $T$ alteration of the host granite and its primary magmatic minerals by sulfate-rich, highly acidic aqueous hydrothermal solutions, associated with the intrusion of Palaeogene andesitic-dioritic rocks. The source of remobilized REE, Th, $\mathrm{U}$ and $\mathrm{P}$ is probably the chemically leached allanite-(Ce) and fluorapatite, possibly with xenotime-(Y) [1]. Supported by the Slovak Research and Development Agency: APVV-15-0050 and APVV-18-0065.

[1] Ondrejka et al. (2018) Min Mag 82, 1277-1300. 